\title{
Reading Between the Red Lines: Loss and Damage and the Paris Outcome
}

\author{
Maxine Burkett \\ Associate Professor of Law, William S. Richardson School of Law, \\ University of Hawai'i \\ burkettm@hawaii.edu
}

\begin{abstract}
For the least-developed countries and small-island states, excluding a standalone provision for loss and damage in the Paris Agreement constituted a red line, one that the negotiating groups refused to cross. For the developed world--and the United States in particular - any possible pathway to liability and compensation that a lossand-damage provision might introduce was an equally bright and impassable red line. In the end, negotiators remained steadfast. Both lines remained more or less unbreached, and compromise language emerged in the Paris Outcome. ${ }^{1}$ This article describes the process leading up to the Outcome, the language included in the lossand-damage provision and its implications, and identifies questions that remain. In particular, the absence of a clear funding stream, the treatment of climate-related displacement, and questions regarding compensation for climate impacts are not completely resolved. These are, perhaps, the most compelling, confounding, and impactful elements of the loss-and-damage debate thus far. Based on the conclusion of the Paris COP, they are likely continue to animate the loss-and-damage discussion for the foreseeable future.
\end{abstract}

\section{Keywords}

Loss and damage - migration - climate finance

1 The Paris Outcome describes the cop Decision Text and its Annex, the draft Paris Agreement. 


\section{The Multi-Decade Road to Paris-In Brief}

\subsection{Understanding Loss and Damage}

Loss-and-damage proposals become more imperative as our multi-decade attempts to reduce emissions and support adaptation continue to founder. Though the UNFCCC does not identify a settled definition of the compound term, 'negative effects of climate variability and climate change that people have not been able to cope with or adapt to' serves as a working definition. ${ }^{2}$ Loss-and-damage proposals attempt to address the impacts of climate change that are not avoided or are unavoidable. ${ }^{3}$ The term concerns the impacts of slow-onset events (such as ocean acidification, desertification, and sea-level rise) and non-economic loss (such as the loss of cultural heritage and displacement), among other things. Limited funding, technology, or institutional capacity may also result in loss and damage, as the harmful impacts are not avoided through adaptation efforts that might be available to wealthier, betterequipped, or better insured communities. ${ }^{4}$ Further, the losses and damages experienced by the most vulnerable countries constitute significant percentages of their GDP and introduce significant setbacks in development. ${ }^{5}$ Loss and damage is, in short, evidence of the collateral effects of inadequate or failed mitigation and the limits of adaptation.

Central to appeals for a loss-and-damage mechanism is a recognition of ethical and legal obligations that such a mechanism would help to advance. As I have explained elsewhere, loss and damage, and particularly its reparative function, would assist vulnerable countries to cope with disasters for which they are least responsible. ${ }^{6}$ While loss-and-damage provisions regarding risk management and risk transfer could address disaster prevention and the need for rapid disbursement of funds, the appeals for compensation and rehabilitation reflect a strong sense among those most vulnerable that emerging

2 See Alex Durand and Saleemul Huq, 'A Simple Guide to the Warsaw International Mechanism on Loss and Damage,' ICCCAD, <www.icccad.net/wp-content/uploads/2015/og/ A-simple-guide-to-the-Warsaw-International-Mechanism.pdf $>$.

3 For a general discussion of different definitions of 'loss and damage' and the limits of adaptation, see Maxine Burkett, 'Loss and Damage', 4 Climate Law 119 (2014).

4 Ilona Millar, Catherine Gascoigne, and Elizabeth Caldwell, 'Making Good the Loss,' in Threatened Island Nations: Legal Implications of Rising Seas and a Changing Climate, edited by Michael B. Gerrard and Gregory Wannier (Cambridge, uk: Cambridge University Press, 2013), at 437 .

5 Ibid.

6 See Burkett, supra note 3; see also Maxine Burkett, 'Climate Reparations', 10 Melbourne Journal of International Law 509 (2009). 
economies and the developed world have a legal and moral obligation to assist them in their survival. Arguments regarding ethical obligations flow from their disproportionately low current and historical contribution to the crisis. Arguments regarding legal obligations stem from provisions within the Framework Convention and follow-on Protocol ${ }^{7}$ as well as existing international law principles such as polluter-pays and common but differentiated responsibilities and respective capabilities. ${ }^{8}$

Because of their unique vulnerability to climate change and their limited wealth and adaptive capacity, the small-island developing states, in particular, have been vocal advocates for a strong and coherent loss-and-damage mechanism under the Framework Convention. ${ }^{9}$ The Alliance of Small Island States (AOSIS) was the negotiating group to introduce early versions of a lossand-damage regime about twenty-five years ago. Initially a proposal seeking insurance-related action, the AOs Is proposal evolved into a three-part mechanism seeking: (i) an insurance component to help vulnerable countries share and transfer risk from increasingly severe weather events; (ii) a rehabilitation and compensatory component to address progressive negative impacts of climate change for which measurable loss and damage is unavoidable, including slow-onset events and unprecedented phenomena such as climate-induced migration; and, (iii) a risk-management component to promote risk assessment and management, as well as to facilitate and inform the other components of the proposal. ${ }^{10}$ AOsIS understood the three components to play 'different and complementary roles' and they comprised an 'integrated' and 'interdependent approach'11 to effective loss-and-damage governance.

AOsIS initially viewed its calls for a loss-and-damage mechanism as a kind of adaptation assistance, which adaptation-related funding might sensibly

7 Ilona Millar et al., supra note 4, at 438 (citing UN FCCC, art. 4(8), Kyoto Protocol, art. 3(14)).

8 Other guiding principles include principles of equity and intergenerational equity and international solidarity. See Alliance of Small Island States, Proposal to the AWG-LCA, 'Multi-Window Mechanism to Address Loss and Damage from Climate Change Impacts' (2008) (on file with author).

9 See Burkett, 'Climate Reparations', supra note 6 (noting that at the '1992 un Conference on Environment and Development, Small Island Developing States were recognized as a special case for both environment and development. Their 'small size, limited resources, geographic dispersion, and isolation from [international] markets' make them vulnerable relative to current development markers).

10 See generally Burkett, supra note 3, at 124; and Aosis, 'Loss and Damage Briefing' (2012) (on file with author).

11 AOSIS, supra note 8. 
support. ${ }^{12}$ Over time, however, the inadequacy of adaptation-in theory and in practice-to support loss-and-damage-related impacts and proposals became clear. Indeed, the desire to distinguish loss and damage definitively from the adaptation regime was a key negotiating issue for the Paris COP and the lead-up to it.

\subsection{The Warsaw International Mechanism and the COP 21 Buildup}

AOSIs's appeals for a loss-and-damage mechanism continued unabated, with notable advances made in the last five years. The 2010 Cancun Adaptation Framework built on important language in the Bali Action Plan regarding enhanced adaptation efforts, including strategies and means to address loss and damage. Cancun's Decision 1/CP.16 launched the Work Programme on Loss and Damage, which the Durban COP elaborated. Doha Decision 3/CP.18 was a significant advance, as it recognized the need to build on 'comprehensive climate risk management approaches' and called for advanced understanding of non-economic loss and damage, patterns of migration and displacement, and identification and development of approaches to rehabilitation..$^{13}$ The Doha decision mandated the formation of an institutional arrangement for the above. From that mandate, the Warsaw International Mechanism (WIM) emerged a year later.

Prior to the WIM, loss and damage had fallen beyond the purview of UNFCCC institutions and funding mechanisms. ${ }^{14}$ Decision 2/CP.19 laid out an approach to developing a loss-and-damage infrastructure. It charged the wiM Executive Committee with enhancing knowledge and understanding of comprehensive risk-management approaches to address loss and damage; strengthening dialogue, coordination, coherence, and synergy among relevant stakeholders relative to loss and damage; and, enhancing action and support. A two-year workplan to implement the wIM's mandate was approved at the COP 20 in 2014; notably, it included an action area on migration, displacement, and mobility. ${ }^{15}$

To be sure, the WIM was an interim measure. It did not have any longterm institutional grounding; in other words, it was a mechanism with a limited period of operation, with the possibility of renewal. Further, it did not identify a clear funding stream. Also noteworthy, despite efforts to have the

12 Ibid.

13 See Burkett, supra note 3 , at 127.

14 See ibid., at 124.

15 UNFCCC, Decision 2/CP.20, 'Warsaw International Mechanism for Loss and Damage', FCCC/CP/2014/10/Add.2. 
loss-and-damage provision reflect the 'beyond adaptation' impacts it is meant to address, the WIM was not created as a standalone mechanism, but rather as a mechanism under the Cancun Adaptation Framework.

Its proponents nevertheless deemed the WIM a qualified victory. Concerns regarding the rehabilitation and compensation component of the proposed multi-window mechanisms reflected ongoing and strident opposition to the possibility that proponents might weave liability for climate impacts into the Framework Convention. While the European Union espoused a more nuanced approach to loss and damage, remaining open to its exclusion yet mindful of its implications for liability, the United States remained ardently opposed to the inclusion of loss and damage wholesale. ${ }^{16}$ These postures portended the deep conflicts in the lead-up to the Paris negotiations, particularly regarding liability and compensation. ${ }^{17}$ The United States' position, however, grew more nuanced. Like the Warsaw meetings, the Paris meetings would see late progress on loss and damage, albeit with key components left on the cutting room floor.

On the road to Paris the most vulnerable nations, in particular the small-island developing states, identified a handful of issues that the Paris agreement had to resolve. Chief among them was inclusion of a standalone loss-and-damage mechanism, distinct from adaptation..$^{18}$ Its inclusion served as a 'red line' for AOSIS - without which the negotiating group would not accede to an agreement. Liability and compensation were a red line for developed-country parties. ${ }^{19}$ Fear of unlimited liability resulting from a standalone agreement represented one of the thomiest issues negotiators faced, rendering loss and

16 See Burkett, supra note 3 , at 124.

17 See discussion of nuanced positions regarding compensation and liability, in ibid., at 129.

${ }_{18}$ See, e.g., Alliance of Small Island States, 'Paris Must Show Global Solidarity to Tackle Climate Change', 29 Nov. 2015, <http://aosis.org/paris-must-show-global-solidarity -to-tackle-climate-change/ $>$; and Pacific Island Development Forum Secretariat, 'Suva Declaration on Climate Change', 4 Sept. 2015, <http://pacificidf.org/wp-content/ uploads/2013/o6/PACIFIC-ISLAND-DEVELOPMENT-FORUM-SUVA-DECLARATION-ON -CLIMATE-CHANGE.v2.pdf >.

19 See Meinhard Doelle, 'The Paris Agreement: Historic Breakthrough or High Stakes Experiment?', 6(1-2) Climate Law (2016) (this issue of the journal) (noting that the United States and Australia sought to keep loss and damage out of the agreement altogether, or at least confining it to the narrow WIM mandate). 
damage among the disputes with the greatest potential to dash hopes for a meaningful and binding agreement in Paris. ${ }^{20}$

It is difficult to overstate the degree to which loss and damage remained a wedge issue leading up to, and over the course of, the negotiations at Le Bourget. Loss-and-damage 'Die-Ins' ${ }^{21}$ provided a counter-balance to the sometimes sympathetic, yet steadfast, rhetoric of the Obama Administration-which noted the President's own island roots yet objected to potential legal remedies and, earlier in the negotiations, related demands to keep temperature increase below $1.5^{\circ} \mathrm{C} .{ }^{22}$ The latter, incidentally, would inversely and positively impact the severity of climate-related loss and damage if achieved. ${ }^{23}$

The negotiating drafts reflected this schizophrenia. ${ }^{24}$ Though earlier drafts included options to make no reference to loss and damage at all, during the COP 21 negotiations the United States indicated its openness to including it in the agreement, clearing a path for its inclusion-as long as it did not expose wealthy countries to compensation claims. ${ }^{25}$ Loss-and-damage advocates, and island negotiators in particular, were mindful of wealthy-country concerns regarding liability and the need for compromise language to address it. ${ }^{26}$ Article 8 of the draft Paris Agreement and paragraphs 48 to 52 of the accompanying Decision text are, together, the product of that compromise.

20 See, e.g., John Upton, 'Paris Pact May Hinge on "Loss and Damage" Dispute', Climate Central, 11 Nov. 2015, at <www.climatecentral.org/news/dispute-threatens-paris-climate -agreement-19666>. As Upton notes, this fear dissipated as a published draft agreement included more conciliatory language, including language that would explicitly limit liability claims under the Paris Agreement.

21 Ben Adler, "Here's why the words "loss and damage" are causing such a fuss at the Paris climate talks', Grist, 8 Dec. 2015, <http://grist.org/climate-energy/heres-why-the-words -loss-and-damage-are-causing-such-a-fuss-at-the-paris-climate-talks/ $>$.

22 See Tony Dokoupil, 'Climate change reparations: What does the U.S. owe?', MSNBC, 2 Dec. 2015, <www.msnbc.com/msnbc/climate-change-reparations-what-does-the-us-owe-1>.

23 It ultimately was achieved. See Paris Agreement', art. 2. Whether or not this is even feasible given the current state of the climate remains unclear. Indeed, if optimally successful, the loss-and-damage mechanism might incite the largest emitters to redouble their efforts on mitigation as well as finance-which in combination will, in small part, reduce the need for more extensive loss-and-damage responses.

24 See, e.g., <http://unfccc.int/files/bodies/awg/application/pdf/adp2-10_e_04sep2015t1900 _wds.pdfs.

25 See, e.g., Pilita Clark, 'COP 21: Small island states hopeful of climate damage deal', Financial Times, 6 Dec. 2015, <www.ft.com/cms/s/o/69856762-9c19-11e5-b45d-4812f2ogf861 .html\#axzz3y1ovAzOz>.

26 Lisa Friedman, 'Obama defends climate diplomacy, back aid for islands', E\&E Reporter, 1 Dec. 2015, <www.eenews.net/stories/1060028763>. 
Under the Agreement, the cop, which can enhance and strengthen the WIM in order to address the adverse effects of loss and damage, will guide and exercise authority over the mechanism. The Decision includes important additional clarifying language. Notably, with respect to migration, the Executive Committee will establish a task force to 'complement, draw upon the work of and involve, as appropriate existing bodies and expert groups ... to develop recommendations for integrated approaches to avert, minimize and address displacement related to the adverse impacts of climate change. ${ }^{27}$ This provision sharply contrasts with earlier drafts of the proposed agreement that vacillated, on the one hand, between a more fully articulated proposal for a climate-change-displacement facility, and, on the other, no mention of climaterelated displacement at all. With regard to the contentious issue of liability and compensation, the Decision states concisely: 'Article 8 of the Agreement [which is the article on Loss and Damage] does not involve or provide a basis for any liability or compensation. ${ }^{28}$ This met the needs for negotiators eager to pass a consensus agreement. It leaves, however, a number of key issues unresolved.

\section{Lingering Questions}

\subsection{The Cutting Room Floor}

The loss-and-damage provisions are notable in that they affirm the parties' commitment to loss and damage and recognize adaptation's constraints and the failures of mitigation efforts to date. Further, they are now outside of the adaptation infrastructure, ostensibly allowing for discrete management and financial support. Loss and damage requires, however, further elaboration to be successful. Among the key details that the Paris Outcome does not resolve is the funding for loss and damage, in addition to the displacement and liability concerns, discussed in greater detail below.

With regard to funding, article 8 of the Agreement does not include any language on how the cop will fund the cooperative and facilitative actions outlined. Further, loss and damage is not included in article 9, which provides financial resources to assist developing countries with mitigation andadaptation only. Earlier drafts included this undoubtedly controversial statement of financial support. The 5 December draft, for example, still included support through a financial mechanism of the Convention in its loss-and-damage article. ${ }^{29}$

27 Decision 1/CP.21, para. 50.

28 Decision 1/CP.21, para. 52.

29 UNFCCC, Draft decision -/CP.21, 'Draft Paris Agreement', FCCC/ADP/2015/L.6, 5 Dec. 2015. The 6 November draft also included similar language. Draft agreement and draft 
Of course, this was bracketed language. The draft's article on finance, and the related draft decision text, also mentioned the provision of adequate support for loss and damage, with explicit reference to supporting the development and implementation of loss-and-damage strategies. ${ }^{30}$

Like adaptation, loss and damage will require a redoubled effort to buoy the institutional advances it has made so far. ${ }^{31}$

\subsection{The Task Force for Climate Change Displacement}

In the course of the year leading up to COP 21, climate-related displacement was prominent in draft texts. Early drafts of the agreement included a firsttime elaboration of a 'climate change displacement coordination facility' under the proposed loss-and-damage provisions. The facility would assist with coordinated efforts to address the needs of those displaced by climaterelated extreme events and plan for organized relocation. ${ }^{32}$ Australia opposed this facility, decrying it as a less effective and less efficient way to advance meaningful international action vis-à-vis migration and displacement. Other formidable parties-including the United States, the United Kingdom, and France-were open to its inclusion, which is, perhaps, why it reemerged as a clear component of the 10 December draft agreement. ${ }^{33}$ Ultimately, only a task force on climate change displacement is left in the Decision. ${ }^{34}$

It also indicates, perhaps, a different kind of compromise - this time among developed-country parties. It may foreshadow disagreement on optimal global management of climate-related migration, displacement, and mobility. If tackled in earnest, however, the task force's efforts may activate critically important work that was already a stated action area for the WIM $^{35}$ but has been, on

decision on workstreams 1 and 2 of the Ad Hoc Working Group on the Durban Platform for Enhanced Action, ADP.2015.11 Informal Note, Edited Version of 6 November 2015, reissued 1o November 2015 .

30 UNFCCC, Draft decision -/CP.21, 'Draft Paris Agreement', FCCC/ADP/2015/L.6, 5 Dec. 2015.

31 See, e.g., Decision 1/CP.21, para. 115 (strongly urging significant increase in adaptation finance).

32 See, e.g., UnfCCC, Draft decision -/CP.21, 'Draft Paris Agreement', FCCC/ADP/2015/L.6, 5 Dec. 2015.

33 Oliver Milman, 'UN drops plan to help move climate-change affected people', The Guardian, 4 Nov. 2015, <www.theguardian.com/environment/2015/oct/07/un-drops-plan-to-create -group-to-relocate-climate-change-affected-peoples.

34 Decision $1 /$ CP.21, para. 50.

35 'Initial two-year workplan of the Executive Committee of the Warsaw International Mechanism for Loss and Damage', <http://unfccc.int/adaptation/workstreams/loss_and _damage/items/8805.php> (approved by UNFCCC Decision 2/CP.20). 
balance, advanced further by other UN agencies and NGOS thus far. ${ }^{36}$ There is a core coordination role the task force could play. Further, among the many issues that the task force could advance-and, perhaps, resolve-are how best to organize migration and planned relocation, how to fund the planning for, and movement of, individuals and communities, how to generate and distribute those funds over time, and how to do all of the above in a principled manner. ${ }^{37}$

\subsection{The Liability and Compensation Row-Death or Redux}

Compensation has been wildly contentious since the heated negotiations leading up to COP 19 in Warsaw. It was similarly contentious, and potentially derailing, at the Paris COP, as the most vulnerable states pressed for inclusion of loss and damage in the agreement. ${ }^{38}$ While compensation is just one of the three components of the AOsis loss-and-damage proposal, it has outsized significance because of concerns that it could lead to developed-country liability for the impacts of current and historic emissions. Proponents of loss and damage were not uniform in their insistence on compensation. With best-case emission scenarios and the extreme-weather events experienced and forecast, however, many loss-and-damage proponents have not wished to foreclose their options to pursue compensation for unavoidable and uninsurable climate change impacts. ${ }^{39}$ Yet, as I have noted, in order to advance the inclusion of a loss-and-damage provision in the Agreement, the Decision explicitly excludes liability and compensation claims based on Article 8 .

The final language on liability claims results from earlier-and tellingiterations on the nature of that exclusion. For example, the 10 December draft of the agreement contained an option to include loss and damage but 'in a manner that does not involve or provide a basis for liability or compensation

36 See Jessica Wentz and Michael Burger, 'Designing a Climate Change Displacement Coordination Facility: Key Issues for COP 21', Sabin Center for Climate Change Law, at 6 <https://web.law.columbia.edu/sites/default/files/microsites/climate-change/unfccc _climate_change_displacement_coordination_facility.pdf>.

37 On possible functions of a climate-displacement facility or task force, see Wentz and Burger, supra note 36 .

${ }_{3} 8$ Julie-Ann Richards, 'Paris climate deal needs solidarity on loss and damage', Climate Change News, 11 Nov. 2015, <www.climatechangenews.com/2015/11/25/paris-climate-deal-needs -solidarity-on-loss-and-damage/>.

39 See generally Maxine Burkett, 'Rehabilitation: A Proposal for a Climate Compensation Mechanism for Small Island States', 13 Santa Clara Journal of International Law 81 (2015); and IISD, 'Summary of the Paris Climate Change Conference: 29 November-13 December 2015', 12(663) Earth Negotiations Bulletin 1 (2015), at 43 . 
nor prejudice existing rights under international law'40 The exclusion is now firmly in the Decision, although absent the language regarding existing rights. This move and modification may, on balance, signal a win for loss-and-damage advocates. ${ }^{41}$ More than any other element of the Decision, however, this paragraph begs the question of the Decision's legal significance. The relative weight of the Decision, its relationship to the Agreement, and the binding nature of the Agreement itself is relevant to a whole host of issues raised during the negotiations. This was of particular concern for COP 21, as delegates, consistent with the Durban mandate, sought to produce a binding agreement in Paris. The legally binding nature of the Agreement is discussed elsewhere in this issue of the journal; however, regarding the reach of paragraph 52 of the Decision, we should recall that a cop decision is not binding unless there is a 'hook' in the treaty that gives it legal force. ${ }^{42}$ There is no identifiable provision in the UNFCCC that would lend legal force to the prohibition of claims for compensation based on Article 8 of the Agreement.

Further, regardless of the nature of the Decision, many commentators and delegates have noted that there are existing avenues for liability and compensation under international law that paragraph 52 cannot foreclose. ${ }^{43}$ The no-harm and polluter-pays principles, for example, are cornerstones of international environmental law, as are prohibitions against, and compensation for, transboundary harm. ${ }^{44}$ All of these principles, and others proposed, are

$40 \quad$ UNFCCC, Draft decision -/CP.21, 'Draft Paris Agreement', COP 21 agenda item 4 (b), 1o Dec. 2015 .

41 IISD, supra note 39 , at 43 .

42 See Daniel Bodansky, 'Legally Binding Versus Non-Legally Binding Instruments', in Towards a Workable and Effective Climate Regime, edited by Scott Barrett, Carlo Carraro, and Jaime de Melo (London: CEPR Press and Ferdi, 2015).

43 See, e.g., Clark, supra note 25 (quoting James Fletcher of St. Lucia): 'We believe we already have avenues for liability and compensation under international law and international agreements. The discussion going on right now is a discussion among lawyers. How do we end up with a text that allays the fears of the Us, the EU and other countries that we are creating a mechanism for liability and compensation. And how do you address our concern that we do not give up any rights that we presently already have under international agreements.' See also, Millar et al., supra note 4 , at 438 (citing relevant provisions in the International Law Commission, 'Responsibility of States for Internationally Wrongful Acts', UN ILC, 53d Sess. (2001)).

44 See UnfCcc Preamble, FCCC/Informal/84; see also, Report of the International Law Commission, 5erd Session, 'Draft Articles on Prevention of Transboundary Harm from Hazardous Activities, with Commentary', 2001, A/56/10; Christopher Schwarte and Will Frank, 'The International Law Association's Legal Principles on Climate Change 
relevant to the circumstances of global climate change. ${ }^{45}$ Moreover, some developing-country delegates made their concerns regarding the spirit and text of paragraph $5^{2}$ clear. Nicaragua and Bolivia, in particular, bemoaned the presence of language attempting to delimit rights to compensation and access to 'climate justice. ${ }^{46}$ This and related issues might reemerge in the near term.

Based on the above, the ability of parties to pursue liability claims through other avenues, or by revisiting the COP 21 Decision, does not appear to be at stake. What is at stake is the trust and solidarity-building between negotiating blocs that the loss-and-damage compromises may have inaugurated. Article 8 and related provisions were the product of a hard-fought conciliation between the highest emitters and the most vulnerable, with least-developed countries and small-island states deferring complete satisfaction with the text for a global consensus in Paris. While there is nothing that legally forecloses future discussions on liability and compensation, there may be substantial political ramifications that can impede follow-on decision-making.

\section{Conclusion}

With COP 21 negotiations well in the rear view, the enormity of the task at hand is abundantly clear. The extreme events facing those most exposed and leastequipped to manage them dwarf the notable successes in Paris. Achieving a standalone loss-and-damage provision was one of those successes, to be sure, though it was just a foothold. The future action it enables will determine its actual significance. In the meantime, there are housekeeping details and larger definitional challenges that the wIM will need to tackle with its broadened and weightier mandate-a mandate that came on the heels of noted concern with its limited progress on implementation of the two-year workplan. ${ }^{47}$ The

and Climate Liability Under Public International Law,' 4 Climate Law 201-216 (2014); and Doelle, supra note 19 .

45 For an impassioned argument, see, e.g. Tim Crosland, Vulnerable countries warned: Protect your legal rights in a Paris accord', Climate Change News, 23 Oct. 2015, <www .climatechangenews.com/2015/10/23/vulnerable-countries-warned-protect-your-legal -rights-in-a-paris-accord/>. Crosland notes that successful climate litigation may no longer be elusive, citing to the recent Urgenda and Leghari cases.

46 IISD, supra note 39, at 12; see also Francesco Sindico, 'A Story of 2.o Texts and the Landing of the Paris Agreement' (Working Paper No. 3, Strathclyde Centre For Environmental Law and Governance, University of Strathclyde Glasgow, 2015), <www.strath.ac.uk/media/ faculties/hass/law/scelg/WORKING_PAPER_3_-MERGED.pdf $>$. 
definitional challenges involve the very attribution of an extreme-weather event to past anthropogenic emissions, ${ }^{48}$ a foundational determination for loss and damage.

The small-island states are clear-eyed about the work needed to advance loss and damage and the wim. They also justifiably paused to celebrate the fortitude, coupled with diplomacy, that resulted in an 'historic agreement.'49 Indeed, moving ahead, the unresolved issues-those that continue to occupy the space between the two red lines-will require a similar mix of fortitude and diplomacy.

48 See Friederike Otto, Rachel James, and Myles Allen, 'The science of attributing extreme weather events and its potential contribution to assessing loss and damage associated with climate change impacts,' Environmental Change Institute, <www.eci.ox.ac.uk>; Christina Huggel, Dáithí Stone, Maximilian Auffhammer, and Gerrit Hansen, 'Loss and damage attribution', 3 Nature Climate Change 694 (2013), at 696 (noting that despite the level of uncertainty in future climatic conditions, a risk-attribution framework can support policymakers by indicating the relative, up-to-date contribution of risk drivers--including climatic ones-to overall risk, which is eventually the determinant for loss and damage).

49 Alliance of Small Island States, 'Closing Statement Paris Agreement,' 12 December 2015, $<$ http://aosis.org/closing-statement-paris-agreement/>. 